\title{
WYMÓG GRAFICZNEJ PRZEDSTAWIALNOŚCI JAKO PRZESŁANKA ZDOLNOŚCI OCHRONNEJ ZNAKU TOWAROWEGO W PRAWIE UNIJNYM - AKTUALNE KONCEPCJE ORAZ PLANOWANE ZMIANY
}

\section{Uwagi ogólne}

Wymóg graficznej przedstawialności oznaczenia zgłoszonego w celu uzyskania prawa ochronnego na znak towarowy jest jednym z dwóch istotnych kryteriów przyznawania ochrony prawnej. ${ }^{2}$ Drugim istotnym kryterium zdolności ochronnej znaku towarowego jest dystynktywność, czyli zdolność odróżniająca, jaką muszą charakteryzować się oznaczenia, które opatrują towary lub usługi, aby doszło do jednoznacznej identyfikacji z przedsiębiorcą, wprowadzającym je na rynek. Wspomniane wymogi są ze sobą ściśle powiązane. Trudno jest bowiem zweryfikować zdolność odróżniającą znaku, jeżeli nie jest on ujęty w pewnych ramach graficznej przedstawialności. Tematyka ta budzi wątpliwości judykatury i doktryny od przeszło trzydziestu lat, na przestrzeni których formy przedstawieniowe znaków towarowych ewoluowały i obecnie mogą być percypowane różnymi zmysłami, co utrudnia ich przedstawialność w sposób graficzny. Współczesne regulacje unijne w zakresie prawa własności przemysłowej zawierają otwarty katalog form przedstawieniowych znaków towarowych, co niejednokrotnie wzbudza kontrowersje związane z należytym ustaleniem przedmiotu ochrony. ${ }^{3}$

Graficzna przedstawialność znaku towarowego istotna jest już na etapie zgłoszenia znaku w odpowiednim urzędzie patentowym, w celu uzyskania prawa wyłącznego, jak również podczas jego używania w obrocie gospodarczym. Wprowadzenie do prawa znaków towarowych wymogu graficznej przedstawialności jest uwarunkowane przede wszystkim realizacją funkcji publikacyjnej związanej z wpisem do

Rzecznik patentowy, doktorant w Akademii Leona Koźmińskiego w Warszawie.

J. Sieńczyło-Chlabicz, Prawo własności intelektualnej, Warszawa 2011, s. 337-338.

M. Ziółkowski, Rodzaje znaków towarowych ze względu na ich percepcję zmysłami oraz przedstawialność w rejestrze, „Przegląd Prawa Handlowego” 2015, nr 1, s. 54-58. 
rejestru, co ma zapewniać uczestnikom rynku, w szczególności przedsiębiorcom, możliwość uzyskania jasnej i jednoznacznej informacji o zgłoszonych i zarejestrowanych znakach towarowych i w konsekwencji precyzyjnie określać treść prawa i zakres ochrony znaku towarowego.

Celem artykułu jest analiza wymogu graficznej przedstawialności jako przesłanki zdolności ochronnej znaku towarowego w prawie unijnym z uwzględnieniem obowiązujących uregulowań oraz tendencji w orzecznictwie. Artykuł odnosi się do aktualnej interpretacji wymogu graficznej przedstawialności oraz uwzględnia projektowane zmiany przepisów prawa unijnego w tym zakresie.

\section{Wymóg graficznej przedstawialności w Dyrektywie nr 89/104/EWG oraz Dyrektywie nr 2008/95/WE}

Po kilkunastu latach pracy nad projektem aktu, którego celem było zharmonizowanie zagadnień materialnoprawnych dotyczących znaków towarowych w poszczególnych państwach członkowskich UE, powstała Pierwsza Dyrektywa Rady 89/104/ EWG z dnia 21 grudnia 1988 r. w sprawie zbliżenia ustawodawstw państw członkowskich odnoszących się do znaków towarowych. ${ }^{4}$ Harmonizacja objęła również definicję znaku towarowego. ${ }^{5}$ Dyrektywa 89/104/EWG miała bowiem za zadanie ujednolicić przepisy dotyczące prawa znaków towarowych, obowiązujące w państwach członkowskich w celu stworzenia optymalnych warunków dla sprawnego funkcjonowania wspólnotowego rynku wewnętrznego. ${ }^{6}$

Artykuł 2 Dyrektywy 89/104/EWG stanowił, iż znak towarowy może składać się z jakiegokolwiek oznaczenia, które można przedstawić w formie graficznej, pod warunkiem, że takie oznaczenie umożliwia odróżnianie towarów lub usług jednego przedsiębiorstwa od towarów lub usług innych przedsiębiorstw. ${ }^{7} \mathrm{~W}$ dalszej części tego artykułu wyszczególniony został otwarty katalog oznaczeń, które ów wymóg mogą spełniać. Znaki towarowe mogą składać się z wyrazów (łącznie z nazwiskami), rysunków, liter, cyfr, kształtu towarów lub kształtu opakowań. ${ }^{8}$ Pomimo braku jednoznacznego wskazania, ze względu na otwarty katalog znaków, nie zostały wyłączone

Dz. Urz. WE L 40 z 1989 r.

T. Płachtej, Urząd ds. Harmonizacji Rynku Wewnętrznego w Alicante jako wyspecjalizowany organ Unii Europejskiej w zakresie ochrony praw własności przemysłowej, „Przegląd Ustawodawstwa Gospodarczego” 2011, nr 1, s. 29; por. I. Schwartz, The Rationale of the approximation Directive and the Regulation on Community trademarks, „International Review of Intellectual Property and Competition law” 1981, nr 12, s. 319-335; E. Armitage, The CTM: Comments on the latest drafts of the proposed EEC Regulation and Directive, „European Intellectual Property Review" 1981, nr 3, s. 72-79.

6 D. Kiedrowska, Zdolność rejestrowa znaków dźwiękowych, „Rzecznik Patentowy” 2003, nr 1-2, s. 68.

7 Por. J. Bornkamm, Harmonising Trade Mark Law in Europe, „Intellectual Property Quarterly” 1999, nr 3, s. 292-294.

8 W. Tabor, E. Wojcieszko, Polskie prawo znaków towarowych a wytyczne EWG (problemy harmonizacji), ,Zeszyty Naukowe Uniwersytetu Jagiellońskiego, Prace z Prawa Własności Intelektualnej”, z. 60, 1993, s. 12; R. Skubisz, Wytyczne o ujednoliceniu przepisów prawa w państwach-członkach EWG w dziedzinie znaków towarowych i usługowych. Próba oceny znaczenia dla polskiego prawa znaków towarowych, „Zeszyty Naukowe Uniwersytetu Jagiellońskiego, Prace z Prawa Własności Intelektualnej” 1993, z. 60, s. 26. 
Wymóg graficznej przedstawialności jako przesłanka zdolności ochronnej...

z ochrony oznaczenia w postaci kolorów oraz dźwięków. ${ }^{9}$ Brzmienie angielskiego tekstu Dyrektywy 89/104/EWG w odniesieniu do wymogu graficznej przedstawialności było następujące: „A trade mark may consist of any sign capable of being represented graphically, particularly words, including personal names, design, letters, numerals, the shape of goods or of their packaging (...)".

W dniu 22 października 2008 r. Parlament Europejski i Rada uchwaliły Dyrektywę 2008/95/WE w sprawie zbliżenia ustawodawstw państw członkowskich odnoszących się do znaków towarowych, ${ }^{10}$ która weszła w życie z dniem 28 listopada 2008 r. Dyrektywa 2008/95/WE, zastępująca Dyrektywę 89/104/EWG, przyjęła niezmienioną w stosunku do poprzednio obowiązującej definicję znaku towarowego. Nie zostały zmienione także inne kluczowe przepisy. ${ }^{11}$ Wymóg graficznej przedstawialności nie został zawężony ani rozszerzony w odniesionemu do jakichkolwiek nowych form znaków towarowych i zachowany został otwarty katalog oznaczeń mogących charakteryzować się przedstawialnością w formie graficznej. ${ }^{12}$

Biorąc pod uwagę wyżej przedstawioną definicją znaku towarowego, żadne oznaczenie nie może być automatycznie wyłączone z możliwości uzyskania rejestracji - każdy znak może bowiem potencjalnie uzyskać ochronę, jeżeli spełnione zostaną dwa kryteria wskazane w definicji - możliwość graficznego przedstawienia oraz zdatność do odróżniania towarów lub usług jednego podmiotu od towarów lub usług innych podmiotów. ${ }^{13}$ Uregulowania zawarte we wspomnianych Dyrektywach zostały transponowane do prawa polskiego, a przesłanka graficznej przedstawialności jest również jednym z kryteriów przyznania ochrony znakom towarowym na gruncie ustawy Prawo własności przemysłowej. ${ }^{14}$ Zgodnie z art. 120 ust. 1 p.w.p. znakiem towarowym może być każde oznaczenie, które można przedstawić w sposób graficzny, jeżeli oznaczenie takie nadaje się do odróżnienia towarów jednego przedsiębiorstwa od towarów innego przedsiębiorstwa. Art. 120 ust. 2 p.w.p. zawiera natomiast przykładowe wyliczenie form przedstawieniowych znaków towarowych.

9 Ch. Gielen, European trade mark legislation: the Statements, „European Intellectual Property Review” 1996, nr 18 (2), s. 83-89.

10 Dz. Urz. UE L 299 z 2008 r.

11 Szerzej: E. Jaroszyńska-Kozłowska, M. Trzebiatowski, Dyrektywa o znakach towarowych po „liftingu”, „Monitor Prawniczy” 2009, nr 1; R. Skubisz, M. Trzebiatowski, Znaki towarowe w prawie międzynarodowym i prawie Unii Europejskiej, „Studia Prawa Prywatnego” nr 1, 2010, s. 140.

12 K. Szczepanowska-Kozłowska, Znaki towarowe w Unii Europejskiej (I), „Przegląd Prawa Handlowego” 2004, nr 8, s. 5.

13 L.G. Schmidt, Definition of a trademark by the European trademark regime - theoretical exercise?, „International Review of Intellectual Property and Competition law" 1999, nr 7, s. 1.

14 Ustawa z dnia 30 czerwca 2000 r. - Prawo własności przemysłowej (tekst jedn. Dz.U. z 2013 r. poz. 1410), dalej jako p.w.p. 


\section{Wymóg graficznej przedstawialności w Rozporządzeniu Rady nr 40/94 oraz Rozporządzeniu Rady nr 207/2009}

Rozporządzenie Rady 40/94 z dnia 20 grudnia 1993 r. $^{15}$ oraz zastępujące je Rozporządzenie Rady nr 207/2009 z dnia 26 lutego 2009 r. w sprawie wspólnotowego znaku towarowego, ${ }^{16}$ które weszło w życie z dniem 13 kwietnia 2009 r., przewiduje możliwość uzyskania jednego prawa z rejestracji znaku towarowego na terytorium wszystkich państw UE, niezależnie od praw wyłącznych udzielanych na podstawie krajowych systemów ochrony znaków towarowych. ${ }^{17}$ Prawo z rejestracji na wspólnotowy znak towarowy istnieje obok praw krajowych, chociaż coraz częściej jest wybierane przez przedsiębiorców zamiast oddzielnych rejestracji krajowych, ze względu na terytorialną rozpiętość ochrony. ${ }^{18}$

W omawianych rozporządzeniach definicja znaku towarowego oraz wymóg graficznej przedstawialności nie różnią się od definicji zawartej w dyrektywach. ${ }^{19}$ Pomimo pewnych wątpliwości w doktrynie, co do konieczności wprowadzenia kryterium graficznej przedstawialności zamiast szerszego wymogu przedstawialności, ze względów administracyjno-technicznych związanych z prowadzeniem rejestrów, utrzymano kryterium graficznej przedstawialności. ${ }^{20}$

Brzmienie angielskiego tekstu rozporządzenia 40/94 w odniesieniu do definicji znaku towarowego oraz wymogu graficznej przedstawialności jest następujące: „A Community trade mark may consist of any signs capable of being represented graphically, particularly words, including personal names, designs, letters, numerals, the shape of goods or of their packaging, provided that such signs are capable of distinguishing the goods or services of one undertaking from those of other undertakings.” Tożsama definicja znalazła się również w rozporządzeniu 207/2009.

15 Dz. Urz. UE L 11 z dnia 14 stycznia $1994 \mathrm{r}$.

16 Dz. Urz. UE L 78 z dnia 24 marca 2009 r.

17 Zob. U. Promińska, Europejski znak towarowy - wybrane aspekty prawne, „Palestra” 1996, nr 1/2, s. 55-66;

G. Wurtenberger, The enforcement of judgments of Community trade mark courts, „Journal of Intellectual Property Law \& Practice" 2012, vol. 7, nr 5, s. 373-374.

18 Por. T. Płachtej, Urząd ds. Harmonizacji..., op. cit., s. 29; L.-A. Duran, The New European Trademark Law, „Denver Journal of International Law and Policy” 1995, vol. 23 (3), s. 489-499; T. W. Blakely, Beyond the International Harmonization of Trademark Law: The Community Trade Mark as a Model of Unitary Transnational Trademark Protection, "University of Pennsylvania Law Review" 2000, vol. 149, s. 337-344; Study on the Overall Functioning of the European Trade Mark System, Max Planck Institute for Intellectual Property and Competition Law, Munich, s. 45, www.ec.europa.eu (data dostępu: 15.02.2011 r.).

19 R. Stefanicki, Nowe formy wyrażania znaków towarowych (cz. I), „Radca Prawny” 2008, nr 4-5, s. 45; D. Kiedrowska, Zdolność rejestrowa znaków dźwiękowych, „Rzecznik Patentowy” 2003, nr 1-2, s. 68; U. Promińska, Europejski znak..., op. cit., s. 57; S. Hidaka, N. Tatchell, M. Daniels, B. Trimmer, A. Cooke, A sign of the times? A review of key trade mark decisions of the European Court of Justice and their impact upon national trade mark jurisprudence in the EU, „The Trademark Reporter” vol. 94, September-October 2004, nr 5, s. 1105; K. Szczepanowska-Kozłowska, Znaki towarowe..., op. cit., s. 4; K. Szczepanowska-Kozłowska, Wspólnotowy znak towarowy, „Przegląd Prawa Handlowego” 2004, nr 10, s. 5.

20 F-K. Beier, Od znaku towarowego EWG do znaku Wspólnoty, „Przegląd Prawa Handlowego” 1999, nr 5, s. 18; A. von Mühlendahl, Od znaku towarowego EWG do znaku Wspólnoty, „Przegląd Prawa Handlowego” 1999, nr 7, s. 21; N. Mishra, Registration of non-traditional trademarks, „Journal of Intellectual Property Rights” vol. 13, January 2008 , s. 44. 
Wymóg graficznej przedstawialności jako przesłanka zdolności ochronnej...

\section{Wpływ orzeczenia w sprawie Sieckmann na rozumienie wymogu graficznej przedstawialności}

Obowiązujące regulacje nie zakazują expressis verbis uznania za znaki towarowe takich oznaczeń, które oddziałują na przykład na zmysł węchu, smaku lub dotyku. ${ }^{21}$ Jako że katalog oznaczeń mogących stanowić znak towarowy jest otwarty, należy przyjąć, iż oznaczenia takie mogą być znakami towarowymi. ${ }^{22}$ Potrzeby współczesnego obrotu przesądzają o stałym wzbogacaniu form wyrażeniowych znaku i liberalizacji stanowiska organów rejestrujących. Podstawę dla legalizacji tego rodzaju praktyk stanowi otwarta konstrukcja przepisów, zawierających definicję znaku i regulujących niniejszą materię. ${ }^{23}$

Pomimo otwartego katalogu znaków towarowych mogących podlegać ochronie w państwach członkowskich UE oraz ochronie opartej na rejestracji wspólnotowego znaku towarowego, istotne zasady interpretacji wymogu graficznej przedstawialności wynikają z obowiązującego orzecznictwa ETS (obecnie TSUE). Najistotniejszym judykatem ETS poruszającym kwestię graficznej przedstawialności był wyrok w sprawie Sieckmann.${ }^{24}$ Orzeczenie wydane w tej sprawie oparto na tradycyjnym, a zarazem restrykcyjnym rozumieniu tego wymogu. Sprawa dotyczyła oznaczenia zapachowego, które zostało przedstawione za pomocą opisu słownego - balsamicznie owocowy zapach z delikatną nutą cynamonu - jak również wzoru substancji chemicznej zapachu. ${ }^{25}$ Do zgłoszenia znaku dołączona została także próbka zapachu w specjalnym pojemniku. ${ }^{26}$ Znak towarowy został zgłoszony dla różnego rodzaju usług należących do klas 35, 41 i 42 klasyfikacji nicejskiej, w tym m.in. działalności reklamowej, rozrywkowej, kulturalnej, medycznej oraz kosmetycznej.

W pytaniu prejudycjalnym zadanym ETS, sąd krajowy rozpatrujący sprawę (Bundespatentgericht) dążył do ustalenia, czy znak towarowy może składać się z oznaczenia, które jako takie nie jest dostrzegalne wizualnie. Rozstrzygnięcie sprawy przez sąd krajowy zależało bowiem od ustalenia przez ETS, czy definicję znaku towarowego odnoszącą się do spełnienia kryterium graficznej przedstawialności można traktować w taki sposób, że znaki takie jak zapachy lub dźwięki, pomimo tego, że są niewidzialne, mogą być pośrednio przedstawione w sposób graficzny poprzez ich zapis. ${ }^{27}$ Ponadto sąd krajowy wnosił o ustalenie wymogów przedstawialno-

21 Por. J.K. McGrath, The new breed of trade marks: sounds, smells and tastes, „Victoria University, Wellington Law Review" 2001, nr 32, s. 277-320.

22 J. Mordwiłko-Osajda, Znak towarowy - Bezwzględne przeszkody rejestracji, Warszawa 2009, s. 99; A. Bender, Ph. Von Kapff, Born to be free - the Community Trade Mark in practice, "International Review of Industrial Property and Copyright Law" 2001, nr 6, s. 633.

23 R. Stefanicki, Prawne granice ochrony koloru jako znaku towarowego, „Monitor Prawniczy” 2002, nr 4, s. 169.

24 Wyrok ETS z 12 grudnia 2002 r., Ralf Sieckmann przeciwko Deutsches Patent und Markenamt, C-273/00.

25 Ester metylowy kwasu cynamonowego - $\mathrm{C} 6 \mathrm{H} 5-\mathrm{CH}=\mathrm{CHCOOCH} 3$.

26 J. Mordwiłko-Osajda, Znak towarowy - Bezwzględne..., op. cit., s. 102.

27 R. Skubisz, Komentarz do wyroku Trybunału Sprawiedliwości Wspólnot Europejskich z dnia 12 grudnia 2002 r. Ralf Sieckmann przeciwko Deutsches Patent- und Markenamt sprawa C-273/00, „Rzecznik Patentowy” 2003, nr $1-2$, s. 125. 
ści graficznej, jakie powinien spełniać zapach jako oznaczenie odróżniające, tzn. czy wystarczy: (i) użycie samego wzoru chemicznego, (ii) przedstawienie opisu znaku, (iii) złożenie próbki do depozytu lub (iv) kombinacja powyższych sposobów.

ETS w wydanym wyroku wskazał, że ze względu na nieograniczoną listę form przedstawieniowych wynikających z definicji znaku, zapach może zostać zarejestrowany jako znak towarowy. ETS uznał, że znak towarowy może składać się z oznaczeń, których nie można dostrzec wizualnie, pod warunkiem, że mogą być przedstawione w postaci graficznej. Taka graficzna prezentacja znaku musi umożliwiać jego rozpoznanie za pomocą zmysłu wzroku, zwłaszcza przy użyciu obrazów, linii, symboli, aby każdy podmiot stykający się ze znakiem mógł go precyzyjne zidentyfikować. Tyczy się to przede wszystkim urzędu badającego i rejestrującego zgłoszony znak, jak również uczestników obrotu gospodarczego, w tym konkurentów i konsumentów. ${ }^{28}$

W analizowanej sprawie ETS uznał, że kryterium graficznej przedstawialności nie zostało spełnione. ${ }^{29}$ Wskazał, że graficzne przedstawienie znaku musi być na tyle precyzyjne i jasne, aby było zrozumiałe dla osób, które posiadają interes w zapoznaniu się z rejestrem znaków, w tym konkurentów. ${ }^{30}$ Prezentacja graficzna znaku niekonwencjonalnego musi być jasna, precyzyjna, zwarta, łatwo dostępna, zrozumiała, trwała i obiektywna. Zdaniem ETS opis zapachu, który de facto został przedstawiony w formie graficznej, nie spełnia wymogów jasności, precyzyjności i obiektywności. ${ }^{31}$ Może być bowiem odmiennie interpretowany i subiektywnie rozumiany przez różne stykające się z nim podmioty. Próbka zapachowa uznana została za niestabilną i nietrwałą, ponieważ zapach z upływem czasu ulega zmianom spowodowanym m.in. przez ulatnianie..$^{32}$ Natomiast formuła chemiczna nie jest zrozumiała, bowiem nie każdy będzie w stanie ją odczytać, a także nie dotyczy zapachu, lecz substancji, która ten zapach wytwarza. ${ }^{33}$ Wskazanie wzoru chemicznego jako graficznej reprezentacji zapachu nie umożliwia zidentyfikowania zapachu, co spowodowane jest różnymi czynnikami, takimi jak skoncentrowanie, ilość, temperatura substancji będącej nośnikiem zapachu, które wpływają na sposób zmysłowego

D. Kitchin, D. Llewelyn, C. Mellor, R. Meade, T. Moody-Stuart, D. Keeling, R. Jacob, Kerly's Law of Trade Marks and Trade Names, London 2011, s. 21; K. Levin, Olfactory and Sound Marks in the European Union, „World Intellectual Property Report" April 2003, s. 2.

29 A. Hołda-Wydrzyńska, Graficzne przedstawienie znaku towarowego w świetle ustawy Prawo własności przemysłowej oraz Dyrektywy Rady nr 2008/95/WE, „Problemy Prawa Prywatnego Międzynarodowego”, tom 9, red. M. Pazdan, Prace Naukowe Uniwersytetu Śląskiego nr 2914, Katowice 2011, s. 117.

30 A. Majumdar, S. Sadhu, S. Majumdar, The requirement of graphical representability for non-conventional trademarks, „Journal of Intellectual Property Rights” vol. 11, September 2006, s. 315.

31 E. Wojcieszko-Głuszko, (w:) R. Skubisz, System Prawa Prywatnego, Tom 14 B, Prawo Własności Przemysłowej, Warszawa 2012, s. 472.

32 Por. J.E. Hawes, Fragrances as trademarks, „The Trademark Reporter”, March-April 1989, vol. 79, s. 148-149.

33 J. Mordwiłko-Osajda, Znak towarowy - Bezwzględne..., op. cit., s. 103; J. M. Doliński, Smak oraz jego receptura jako przedmiot praw własności intelektualnej, „Zeszyty Naukowe Uniwersytetu Jagiellońskiego, Prace z Prawa Własności Intelektualnej”, 2012, z. 116, s. 65; E.M. Reimer, A semiotic analysis: developing a new standard for scent marks, „Vanderbilt Journal of Entertainment and Technology Law” 2011-2012, vol. 14, s. 708. 
odbierania zapachu. ${ }^{34}$ ETS stanął na stanowisku, że w odniesieniu do znaków zapachowych wymóg graficznej przedstawialności nie będzie spełniony w żadnym z badanych przypadków. Ani opis słowny, wzór chemiczny, próbka zapachowa, ani kombinacja powyższych zdaniem ETS nie będzie wystarczająca. ${ }^{35}$

ETS potwierdził i zaakcentował istotę wymogu graficznej przedstawialności jako przesłanki zdolności rejestracyjnej znaku towarowego. Uznał, że wymóg ten jest konieczny do: (i) ustalenia jednoznacznego zakresu przyznawanej ochrony, przysługującej uprawnionemu do znaku, (ii) weryfikacji zakresu takiej ochrony przez konkurentów i konsumentów poprzez możliwość analizy publicznie dostępnego rejestru znaków, (iii) dokonywania niezbędnych badań i publikacji przez urząd zajmujący się rejestracją znaków. Każdy podmiot, tj. uprawniony do znaku, konkurenci, konsumenci, jak również urząd dokonujący rejestracji, powinien mieć możliwość jasnego i precyzyjnego określenia zakresu ochrony znaku towarowego.

Wyrok ETS w sprawie Sieckmann stanowi doprecyzowanie wymogu graficznej przedstawialności. Prezentacja graficzna znaku towarowego (konwencjonalnego lub niekonwencjonalnego) musi być bowiem jasna, precyzyjna, zwarta, łatwo dostępna, zrozumiała, trwała i obiektywna. Spełnienie wszystkich tych kryteriów, na etapie rozpatrywania przez urząd patentowy dokonujący rejestracji zgłoszenia np. niekonwencjonalnego niewidzialnego znaku towarowego, może powodować nie lada trudności. Niewątpliwie wyrok ten potwierdza, że przesłanka graficznej przedstawialności może stanowić barierę w uzyskaniu prawa ochronnego na znak towarowy zapachowy.

\section{Planowane zmiany w prawie unijnym}

W dniu 27 marca 2013 r. Komisja Europejska przedstawiła pakiet inicjatyw zmierzających do tego, by rejestracja wspólnotowych znaków towarowych w OHIM, jak również znaków krajowych w poszczególnych państwach Unii Europejskiej była mniej kosztowna, szybsza oraz bardziej przewidywalna. Proponowana reforma ma przyczynić się do zwiększenia popularności rejestracji oznaczeń odróżniających jako znaków towarowych oraz pozwolić skuteczniej korzystać z ochrony znaków w obliczu procederu oznaczania towarów podrabianymi znakami towarowymi wprowadzanymi do obrotu na terytorium UE. ${ }^{36}$

Proponowany pakiet objął trzy inicjatywy: (i) zmianę Dyrektywy 2008/95/ WE mającej na celu zbliżenie ustawodawstw państw członkowskich odnoszą-

34 K. Szczepanowska-Kozłowska, Znaki towarowe..., op. cit., s. 6; V.K. Ahuja, Non-traditional trade marks: new dimension of trade marks law, "European Intellectual Property Review" 2010, nr 11, s. 576.

35 R. Burrell, M. Handler, Making Sense of Trade Mark Law, „Intellectual Property Quarterly” 2003, nr 4, s. 392-394; S. Karapapa, Registering scents as Community trade marks, „The Trademark Reporter” 2010, vol. 100, s. 1337.

36 M. Ziółkowski, Łatwiejsza i tańsza rejestracja, „Rzeczpospolita”, 8 maja 2013 r.; C.S. Petersen, T. Riis, J. Schovsbo, Intellectual property enforcement at the EU border: the challenge of private imports, "Journal of Intellectual Property Law \& Practice" 2012, vol. 7, nr 10, s. 747-762. 
cych się do znaków towarowych, (ii) zmianę Rozporządzenia 207/2009 w sprawie wspólnotowego znaku towarowego oraz (iii) zmianę rozporządzenia w sprawie opłat na rzecz OHIM. Przekształcenie Dyrektywy 2008/95/WE i Rozporządzenia 207/2009 zostało zaproponowane w formie wniosków ustawodawczych, które muszą zostać przyjęte przez Parlament Europejski i Radę w procedurze współdecyzji. ${ }^{37}$

Jedną z proponowanych zmian jest redefinicja wymogu graficznej przedstawialności znaku towarowego. Spełnienie tego kryterium nie budzi wątpliwości, jeżeli zgłaszany jest konwencjonalny znak towarowy składający się z liter, cyfr, czy innej formy postrzegalnej zmysłem wzroku. Jednakże zgłaszający znak w formie nietradycyjnej (np. znak dźwiękowy czy zapachowy), która nie podlega percepcji wizualnej, może spotkać się z zarzutem braku spełnienia przedmiotowego kryterium. W związku z powyższym, podjęta została próba redefinicji tego kryterium. Proponowana zmiana nie ma na celu rozszerzenia zakresu ochrony znaków towarowych, lecz jego doprecyzowanie, bardziej ścisłe ujęcie, przy jednoczesnym zapewnieniu elastyczności definicji znaku towarowego. ${ }^{38}$ Ideą, jaka przyświeca tej propozycji legislacyjnej, jest dopuszczenie możliwości rejestracji znaków niekonwencjonalnych, których jest coraz więcej ze względu na postępujący rozwój technologiczny. Zmiana ta ma dotyczyć zgłoszeń wspólnotowych, jak również krajowych znaków towarowych. Planuje się wprowadzenie definicji odpowiadającej zasadom, przyjętym w wyroku ETS w sprawie Sieckmann. Wymóg graficznej przedstawialności ma zostać zastąpiony - co ma szczególne znaczenie w przypadku znaków niewidzialnych - prezentacją znaku, która będzie jasna, precyzyjna, zwarta, łatwo dostępna, zrozumiała, trwała i obiektywna. Takie doprecyzowanie kryterium przedstawialności znaku, pomimo chęci jego liberalizacji, może jednakże w praktyce doprowadzić do dalszego blokowania rejestracji znaków niekonwencjonalnych niewidzialnych.

\section{Wnioski końcowe}

Podstawowym kryterium rozstrzygającym o tym, czy określony rodzaj oznaczenia może być znakiem towarowym podlegającym ochronie, jest możliwość przedstawienia tego oznaczenia w sposób graficzny. ${ }^{39}$ Rola, jaką w swym założeniu ma do spełnienia warunek graficznej przedstawialności oznaczenia, polega na tym, aby z przedstawienia oznaczenia zawartego w dokumentacji zgłoszeniomającej na celu zbliżenie ustawodawstw państw członkowskich odnoszących się do znaków towarowych (wersja przekształcona), dokument nr 2013/0089 (COD), www.europarl.europa.eu (data dostępu: ...); Komisja Europejska, Wniosek z dnia 27 marca 2013 r. dotyczący rozporządzenia Parlamentu Europejskiego i Rady zmieniającego rozporządzenie Rady (WE) nr 207/2009 w sprawie wspólnotowego znaku towarowego, dokument nr 2013/0088 (COD), www.europarl.europa.eu (data dostępu: 02.03.2015 r.).

38 K. Czub, Wybrane aspekty planowanej nowelizacji rozporządzenia w sprawie wspólnotowego znaku towarowego, „Europejski Przegląd Sądowy” 2013, nr 11, s. 21.

39 J. Sieńczyło-Chlabicz, Prawo..., op. cit., s. 337-338. 
wej wynikał w sposób jednoznaczny zakres żądanej ochrony. ${ }^{40}$ Kryterium graficznej przedstawialności determinuje, jakie oznaczenia są chronione na podstawie prawa ochronnego i zmonopolizowane na rzecz pojedynczych przedsiębiorców, a jakie pozostają w wolnym dostępie dla wszystkich podmiotów prowadzących działalność gospodarczą. ${ }^{41}$

Przesłanka graficznej przedstawialności wydaje się pozornie jednoznaczna w swej treści i dostatecznie precyzyjna. Jednakże jej analiza w kontekście poszczególnych form przedstawieniowych znaku towarowego wywołuje $\mathrm{w}$ praktyce poważne wątpliwości, co znajduje odzwierciedlenie także w piśmiennictwie przedstawiającym zarówno poglądy konserwatywne, jak i liberalne w zakresie interpretacji tej przesłanki. Postuluje się zastąpienie jej obowiązkiem złożenia wraz z wnioskiem o rejestrację znaku towarowego jednoznacznego i niebudzącego wątpliwości odzwierciedlenia znaku, co umożliwiłoby otwarcie prawa znaków towarowych na potrzeby rozwoju nowoczesnych strategii reklamowych, przy wykorzystaniu najnowszej myśli technologicznej. ${ }^{42}$ Obecnie bowiem przesłanka graficznej przedstawialności, niezależnie od prób jej rozszerzającej wykładni, stanowi istotną przeszkodę dla rejestracji nietypowych form znaków towarowych. ${ }^{43}$

Planowane zniesienie wymogu graficznej przedstawialności jest de facto jego doprecyzowaniem. Kryterium to bowiem nie zniknie, lecz zostanie zastąpione bardziej szczegółowymi wytycznymi wynikającymi z wyroku ETS w sprawie Sieckmann. Przedstawienie znaku nie będzie już „graficzne”, ale będzie musiało być jasne, precyzyjne, autonomiczne, łatwo dostępne, trwałe i obiektywne. Ochronie podlegać będą mogły, tak jak dotychczas, znaki percypowane różnymi zmysłami, nie tylko zmysłem wzroku. Wyrok ETS w sprawie Sieckmann, z którego zaczerpnięto wytyczne w zakresie dookreślenia wymogu przedstawialności znaku towarowego, może być uznany za wewnętrznie niespójny. $Z$ jednej strony wprawdzie potwierdzony został otwarty katalog form przedstawieniowych znaków towarowych, w tym możliwość rejestrowania oznaczeń niewidzialnych. $Z$ drugiej zaś strony, wprowadzono bardzo restrykcyjne przesłanki przedstawialności znaku, ograniczając tym samym znacząco możliwość rejestracji znaków nietypowych, ${ }^{44}$ co sprawia, że katalog form przedstawieniowych znaków towarowych, de facto jest katalogiem jedynie na pozór otwartym.

\footnotetext{
40 E. Wojcieszko-Głuszko, Znaki towarowe a ostatnia nowelizacja ustawy - Prawo własności przemysłowej, „Radca Prawny" 2005, nr 2, s. 38-39.

41 J. Mordwiłko-Osajda, Znak towarowy - Bezwzględne przeszkody rejestracji, Warszawa 2009, s. 102.

42 Por. Study on the Overall Functioning of the European Trade Mark System, Max Planck Institute for Intellectual Property and Competition Law, Munich, s. 68, www.ec.europa.eu (data dostępu: 10.03.2015 r.).

43 P. Funka, Zdolność odróżniająca znaku towarowego w aspekcie prawnoporównawczym, „Zeszyty Naukowe Uniwersytetu Jagiellońskiego, Prace z Prawa Własności Intelektualnej” 2006, nr 95, s. 26.

44 A. Hołda-Wydrzyńska, Graficzne przedstawienie znaku towarowego..., op. cit., s. 126.
} 


\section{GRAPHICAL REPRESENTATION REQUIREMENT AS A CONDITION OF TRADEMARK PROTECTION IN EU LAW - CURRENT CONCEPTS AND PLANNED CHANGES}

This article aims to analyze the graphical representation requirement as a condition of trademark protection in the EU law with a review of current regulations and tendencies in case law. The graphical representation requirement was included in the trademark law regulations in accordance with a need for publication of the decision pertaining to trademark registration. The graphical representation requirement is seemingly unequivocal and precise. However, an in depth analysis of the various trademark representations shows some serious doubts. This article also refers to the current interpretation of the graphical representation requirement as well as includes proposed changes in the EU law in this respect. Despite the nonexhaustive list of protectable trademark representations in the EU Member States, as well as in the Community trademark regime, there are concerns in interpretation of the graphical representation requirement.

Słowa kluczowe: znak towarowy, graficzna przedstawialność, prawo unijne, znaki towarowe niekonwencjonalne.

Keywords: trademark, graphical representation, European Union law, unconventional trademarks. 